\title{
Discurso do Dr. Fernand Vrancken
}

DISCURSO DO DR. FERNAND VRANCKEN, PRIMEIRO PRESIDENTE DA CORTE DE CONTAS DA BELGICA. NA SESSÃO SOLENE DE INALIGLRAÇ§O DO CONGRESSO, NA CAMARA IDOS DEPUTADOS, EM 4 DE İMAIO DE 1959

Excelência, permitireis, em seguida, dirigir a saudação mais cordial de nossas instituições nacionais que nos delegaram, a. Sua Excelência Ministro Josí Pereira Lira, Presidente do Tribunal de Contas do Brasil, e a seus eminent $\approx$ colaboradores, que aceitaram hospedar nosso Terceiro Congresso Internacional a agradecer-lhes calorosamente ter assegurado a tarefa árdua e difícil de sua organização.

A presença nesta sessão solene das mais altas autoridades do país e dos representiantes qualificados das nações estrangeiras constitui uma prova evidente da estima de que desfrutam o Tribunal de Contas e seu digno Presidente e traz uma nova prova de que a iniciativa tomada em 1953 pelo Tribunal de Contas da República de Cuba merecia a mais alta consideração .

Congratulamo-nos de ser acolhidos por uma nação da qual, como Belga, pude apreciar a generosidade e da qual conhecemos a altivez, nação da qual os governantes ousam, malgrado as contingências econômicas e sociais às vêzes difíceis, abordar corajosamente o reerguimento e o desenvolvimento, visando, ùnicamente, o bem-estar presente futuro de uma população sempre crescente, esforçando-se de pôr à sua disposição todos os recursos naturais de que é tão rico vosso país.

Repetiu-se com freqüência que o contrôle das finanças da comunidade nacional constitui umí das garantias essenciais das conquistas democráticas, sobretudo quando é exercido por uma instância superior e independente, chamada e prestar conta diretamente aos eleitos representantes da nação.

E' possivel que o cidadão não tenha mais consciência desta vigilância incessante exercida sôbre o emprêgo das contribuições que êle coloca a disposição do poder que êle elegeu; é possivel que os próprios representantes não pensem tãc freqüentemente na eficácia de instituições que são devidas. como no Brasil, assim como o lembrava tão oportunamente o Ministro-Presidente PEREIRA LiRa, a perseverança esclarecida e a energia de outros Rui Barbosa e de outros Serzedelo Correia.

Primitivamente a missão de nossos organismos superiores de contrôle limitava-se à vigilância do emprêgo dos fundos públicos, conforme as auto- 
rizações concedidas pelos Parlamentos; mas sob o império das necessidades econômicas e sociais, o Estado é obrigado a apoderar-se de domínios que até então estavam reservadus à iniciativa privada. Normas práticas administrativas instauraram se, organismos novos instalam-se em lugar das antigas administrações; os Parlamentos vêem-se privados imperceptivelmente de tôda a autoridade e todo o contrôle preventivo sôbre a gestão de bens que, apesar de tudo, pertencem à comunidade e dos quais são responsáveis. Restam apenas nossas instituições para continuar a montar uma guarda vigilante sôbre a manipulação dos dinheiros públicos no interêsse do país, para fazer surgir, se fôr preciso, as responsabilidades que se impõem e prestar conta ao país em seus relatórios anuais, como elas antigamente garantiam -lhe a realidade e a legalidade das contas do Estado.

Certamente, nossas antigas instituições devem adaptar sua missão a essas novas modalidades de administração e de gestão; o ensinamento de experiência recente de algumas de entre elas pode ser útil a outras chamadas a viver semelhante processo de administração.

Destarte, assim. como vos indicava o Ministro-Presidente PEREIRA LIRA, impõe-se cada vez mais à humanidade ou a partes importantes dela colaborações intimas sôbre terrenos cada dia mais variados, econômicos, sociais, militares e culturais, essas colaborações necessitam dos próprios Estados e por conseguinte da coletividade de seus cidadãos da sua contribuição financeira e material. Os cidadãos dos Estados membros não entenderiam. finalmente, que apelos financeiros cada vez mais importantes não acarretem nenhuma responsabilidade e que não sejam feitas regularmente as contas de seus gestores.

Enfim, desde algum tempo, novos povos adquirem o direito de administrar-se por si e solicitam ajuda para organizar sua administração e assegurar utna gestão sã de suas finanças. Sejam quais forem nossas reações nacionais, convém oferecer esta ajuda simplesmente, de maneira a evitar a prepotência de elementos de perturbação e de desordem.

Todavia - permito-me insistir nesse ponto - nossas instituições nacionais nãi querem impor métodos por fôrça de uma maioria eventual em nossos congressus, exercer uma ação sôbre a vontade dos legisladores; somos especialistas em matéria de contrôle das finanças públicas; somos ùnicamerte peritos que estudam as experiências acumuladas e que as oferecem ao exame daqueles que assumem a responsabilidade de legislar para o bem de seu país. As recomendaçñes dos nossos congressos não comprometem nenhum dos participantes, mas serão levadas ao conhecimento das autoridades nacionais ou internacionais competentes.

Tôdas essas razões de interêsse superior, que alguns talvez não apreciem em seu justo valor, têm militado a favor dêstes contatos que nós desejariamıs permanentes entre as instituições de contrôle superior e externo das finanças públicas e que concretizaremos na criação de um Conselho Internacional dais instituições superiores de contrôle das finanças públicas, sôbre o qual sois chamados, meus caros colegas, a deliberar. 
O Congresso do Rio, que acabais de inaugurar solenemente, Senhor Presidente, verá a realização dessa colaboração internacional que se situa já en outros domínios e que trará sua pequena pedra ao edifício imenso e sólido da união dos povos pela paz e a felicidade da comunidade humana.

É a esta obra que vos convido, Senhores e caros colegas, consagreis esta semana de trabalhos nesta cidade que o gênio do homem aperfeiçoou e conquistou ao mar neste quadro de esplendores naturais dominados pela proteção do redentor. 